\title{
A Statistical Study of Trends of Wheat Production in Districts of Eastern Uttar Pradesh, India
}

\author{
Anvesha Singh*, Sri Sunil Kumar, Gopal Krishna Tiwari, Laxmi Devi and Babulal
}

Department of Agricultural Statistics, Acharya Narendra Dev University of Agriculture and Technology, Kumarganj-Ayodhya (UP), 224-229, India

*Corresponding author

\section{Ke y w o r ds \\ Wheat, Growth, Trends, Tabular and Graphical \\ Representation, Simple Growth \\ Rate (SGR) and Compound Growth Rate (CGR) \\ Article Info \\ Accepted: \\ 04 March 2020 \\ Available Online: 10 April 2020}

\section{A B S T R A C T}

\section{Introduction}

Wheat (Triticum aestivum) the world's largest cereal crop belongs to Graminae (Poaceae) family of the genus Triticum. It has been described as the 'King of cereals' because of the acreage it occupies, high productivity and the prominent position in the international food grain trade. Wheat is consumed in a variety of ways such as bread, chapatti, porridge, flour, suji etc.

The term "Wheat" is derived from many different locations, specifically from English,
German and Welsh language. Wheat has good nutrition profile with 12.1 per cent protein, 1.8 per cent lipids, 1.8 per cent ash, 2.0 per cent reducing sugars, 6.7 per cent pentosans, 59.2 per cent starch, 70 per cent total carbohydrates and provides $314 \mathrm{Kcal} / 100 \mathrm{~g}$ of food. It is also good source of minerals and vitamins.

For Wheat production target has been fixed in India for 2019 is 102.19 million tonnes against 100 million tonnes last year. Uttar Pradesh is the largest state with maximum contribution towards national production 
(35.03 per cent) from a large area (35.12 per cent), but with productivity on a lower side of 2.7 tonnes/ha. The wheat production is distributed in three agroclimatic zones, viz. western Uttar Pradesh (3.29 million ha), eastern UP (5.24 million ha) and central Uttar Pradesh (0.68 million ha). The area is 9.2 million ha, with a production of 24.5 million tons and productivity of 2.7 tonnes/ha. The trend during the last five years has shown a marginal decline in production and productivity from nearly stable area of cultivation. Per cent of gross cropped area in 2013-2014 was 40.55. Wheat crop needs clay loam or loam texture and moderate water holding capacity soil and these features are found in Eastern Uttar Pradesh so this region is suitable for wheat production.

The present investigation is proposed with the following objectives includes, to find out general profile of districts of Eastern Uttar Pradesh by way of tabular and graphical representation and to obtain the Growth rates of area, production and yield of Wheat in different districts of Eastern UP based on Time-series data.

\section{Materials and Methods}

This paper dealt with materials and statistical methodologies to carry out the investigation undertaken. In order to study the trends of production, area and productivity in wheat of eastern Uttar Pradesh.

The time series data pertaining to road length, canal length, number of tubewells, number of pumpsets, fertilizer consumption, electricity consumption in agriculture, irrigated area under rice and wheat has been procured from the website http://updes.up.nic.in/spatrika/ spatrika.htm by Economics and Statistics Division, Planning Department, Government of Uttar Pradesh.

\section{Statistical methodologies}

\section{Effect of change in area and productivity on differential production}

An attempt has been made to study the effect of change in area and productivity of crops on differential production between two points of time.

Let $\mathrm{P}, \mathrm{A}$ and $\mathrm{Y}$ be the production, area and productivity of a particular crop at a given point of time. The $\mathrm{P}$ can be expressed as

$\mathrm{P}=\mathrm{Y} \cdot \mathrm{A}$

Let $\Delta \mathrm{P}, \Delta \mathrm{A}$ and $\Delta \mathrm{Y}$ be the change in production, area and productivity of the crop after specific period of time. So we have

$$
\begin{aligned}
& \mathrm{P}+\Delta \mathrm{P}=(\mathrm{A}+\Delta \mathrm{A})(\mathrm{Y}+\Delta \mathrm{Y}) \\
& \mathrm{P}+\Delta \mathrm{P}=\mathrm{AY}+\Delta \mathrm{AY}+\mathrm{A} \Delta \mathrm{Y}+\Delta \mathrm{A} \Delta \mathrm{Y}
\end{aligned}
$$

Therefore we have

$\Delta \mathrm{P}=\Delta \mathrm{AY}+\mathrm{A} \Delta \mathrm{Y}+\Delta \mathrm{A} \Delta \mathrm{Y}$

Thus the total differential production consists of three components:

$\Delta \mathrm{AY}=$ Effect of change in area of crop $\mathrm{A} \Delta \mathrm{Y}=$ Effect of change in productivity of crop

$\Delta \mathrm{A} \Delta \mathrm{Y}=$ Interaction effect due to change in area and productivity of crop.

An attempt has been made to study the effect of change in area and productivity of crops on its logarithmic differential of production between two points of time.

Let $Y_{t}, A_{t}$ and $P_{t}$ be the production, area and productivity respectively, of rice and wheat at 
a given point of time t. The $Y_{t}$ can be expressed as

$Y_{t}=A_{t} P_{t}$

Similarly let $Y_{t-1}, A_{t-1}$ and $P_{t-1}$ be the production, area and productivity, respectively under crops at time point $\mathrm{t}-1$. Then we have

$Y_{t-1}=A_{t-1} P_{t-1}$

The ratio

$\frac{Y_{t}}{Y_{t-1}}=\frac{A_{t}}{A_{t-1}} \frac{P_{t}}{P_{t-1}}$

Taking log of both side, we get

$\log \frac{Y_{t}}{Y_{t-1}}=\log ^{\frac{A_{t}}{A_{t-1}}}+\log ^{\frac{P_{t}}{P_{t-1}}} \quad$ Or

$\log \left(Y_{t}\right)-\log \left(Y_{t-1}\right)=\log \left({ }^{A_{t}}\right)-\log$ $\left({ }^{A_{t-1}}\right)+\log \left({ }^{P_{t}}\right)-\log \left({ }^{P_{t-1}}\right)$

The above expression provided the contribution of logarithmic area and productivity towards logarithmic change in crop production between two points of time, i.e. between $\mathrm{t}-1$ and $\mathrm{t}$.

\section{Trend and growth rate}

\section{Linear function}

Linear fit has been given by the equation

$Y_{t}=\mathrm{a}+\mathrm{bt}$

Where,

$Y_{t_{i}}$ the characteristic (area, production or productivity of dependent variable) $t$ is the time in years, independent variable $\mathrm{a}$ and $\mathrm{b}$ are constants or parameters
The above equation is fitted by using the Ordinary Least Squares (OLS) of estimation. The linear growth rate is calculated by the formula:

Linear growth rate $\left(\right.$ LGR \%) $={ }^{\frac{b}{\bar{y}} \times} 100$

\section{Compound function}

Compound fit has been given by the equation:

$\mathrm{Y}_{\mathrm{t}}=\mathrm{a}^{\mathrm{b}^{\mathrm{t}}} \quad$ Or

$\log ^{Y_{t}}=\log a+t \log b$

Where,

$\mathrm{Y}_{\mathrm{t}}$ is the characteristic (area, production or productivity of dependent Variable)

$t$ is the time in years, independent variable $a$ and $b$ are parameters

The parameters ' $a$ ' and ' $b$ ' are calculated by applying the method of Ordinary Least Squares (OLS). The compound growth rate (CGR \%) is calculated by using the formula:

$\operatorname{CGR}(\%)=(\operatorname{antilog} b-1){ }^{\times} 100$

All growth rates are expressed in percentage. The best fitted function is judged on the basis of $R^{2}$ (coefficient of determination).

\section{Results and Discussion}

\section{The first objective}

To find out general profile of districts of Eastern Uttar Pradesh by way of tabular and graphical representation (Fig. 1-3).

An attempt has been made in this section to capture the important features of Wheat production In Eastern Uttar Pradesh. 
From table 1, 2 and 3

Highest production of Wheat has been observed in Azamgarh district followed by Jaunpur, Barabanki, Gorakhpur and Siddharth Nagar districts based on 3 years moving average.

Highest area under Wheat has been observed in Azamgarh district in respect to top 5 districts of wheat production.

Highest productivity of Wheat has been observed in Siddharth Nagar districts based on 3 years moving average.

Area and productivity contribution by direct and $\log$ method and Cofficient of Variation (CV) of districts at top 5 positions in production of Wheat

Area and productivity contribution by direct and $\log$ method and CV of top 5 districts in production are represented in table 4 .

\section{The second objective}

To obtain the Growth rates of area, production and yield of Wheat in different districts of Eastern UP based on Time-series data.

The annual growth rates of production, area and productivity of Wheat has been worked out using two functions, viz. simple growth rates (SGR) and compound growth rates (CGR) for the districts of Eastern Uttar Pradesh. The results are presented and discussed in table 5 .

\section{Results of table 5}

Highest area growth rate (i.e. 2.01 percent) has been observed in Baharaich district, which is followed by Mau, Barabanki and Siddharth Nagar districts.

Highest production growth rate (i.e. 3.67 percent) has been observed in SiddharthNagar district, which is followed by Sonbhadra and Barabanki.

Highest productivity growth rate (i.e. 3.81 percent) has been observed in Sonbhadra district, which is followed by Shravasti and Siddharth Nagar.

Table.1 Top 5 districts in Production of Wheat

\begin{tabular}{|c|c|c|}
\hline DISTRICT & Area(in hectares) & $\begin{array}{c}\text { Production(in } \\
\text { metric tons) }\end{array}$ \\
\hline AZAMGARH & 233440.33 & 627833.00 \\
\hline JAUNPUR & 210369.67 & 545443.33 \\
\hline BARABANKI & 165901.33 & 532387.00 \\
\hline GORAKHPUR & 190541.33 & 506551.67 \\
\hline $\begin{array}{c}\text { SIDDHARTH } \\
\text { NAGAR }\end{array}$ & 155775.00 & 506342.33 \\
\hline
\end{tabular}


Table. 2 Productivity of top 5 districts in wheat according to production based on 3 years moving average

\begin{tabular}{|c|c|}
\hline DISTRICT & Productivity (q/ha) \\
\hline AZAMGARH & 28.48 \\
\hline JAUNPUR & 25.95 \\
\hline BARABANKI & 32.13 \\
\hline GORAKHPUR & 26.61 \\
\hline SIDDHARTH NAGAR & 32.50 \\
\hline
\end{tabular}

Table.3 Productivity of top districts in wheat based on 3 years moving average

\begin{tabular}{|c|c|}
\hline DISTRICT & Productivity(q/ha) \\
\hline SIDDHARTH NAGAR & 32.42 \\
\hline BARABANKI & 32.13 \\
\hline AMBEDKAR NAGAR & 29.97 \\
\hline MAHARAGANJ & 28.98 \\
\hline SANT KABIR NAGAR & 28.55 \\
\hline
\end{tabular}

Table.4 Area and productivity contribution and CV of wheat

\begin{tabular}{|c|c|c|c|c|c|c|c|}
\hline Districts & \multicolumn{2}{|c|}{ By Direct method } & \multicolumn{2}{c|}{ By log method } & \multicolumn{3}{c|}{ CV } \\
\hline & $\begin{array}{c}\text { Area } \\
\text { contribution }\end{array}$ & $\begin{array}{l}\text { Productivity } \\
\text { contribution }\end{array}$ & $\begin{array}{c}\text { Area } \\
\text { contribution }\end{array}$ & $\begin{array}{l}\text { Productivity } \\
\text { contribution }\end{array}$ & Productivity & Production & Area \\
\hline AZAMGARH & 47.16 & 52.89 & 44.62 & 50.34 & 11.06 & 14.04 & 3.90 \\
\hline GORAKHPUR & 35.42 & 65.22 & 33.13 & 62.86 & 14.34 & 15.69 & 2.59 \\
\hline JAUNPUR & 52.67 & 47.70 & 49.83 & 44.82 & 12.60 & 16.12 & 5.04 \\
\hline SIDDHARTH & 38.70 & 62.17 & 32.39 & 55.08 & 19.49 & 24.46 & 10.10 \\
NAGAR & & & & & & & \\
\hline BARABANKI & 47.55 & 47.06 & 41.51 & 46.85 & 12.72 & 19.47 & 9.71 \\
\hline
\end{tabular}


Table.5 Annual average simple growth rate and compound growth rate (in percentage) of production, area and productivity of Wheat

\begin{tabular}{|c|c|c|c|c|}
\hline \multirow[b]{2}{*}{ DISTRICT } & & \multicolumn{3}{|c|}{ SGR and CGR OF WHEAT } \\
\hline & & PRODUCTION & AREA & PRODUCTIVITY \\
\hline \multirow[t]{2}{*}{ CHANDAULI } & SGR & 2.15 & 0.78 & 1.35 \\
\hline & CGR & 1.98 & 0.79 & 1.18 \\
\hline \multirow[t]{2}{*}{ VARANASI } & SGR & 0.49 & 0.14 & 0.34 \\
\hline & CGR & 0.41 & 0.15 & 0.26 \\
\hline \multirow[t]{2}{*}{ JAUNPUR } & SGR & 2.04 & 0.93 & 1.12 \\
\hline & CGR & 1.97 & 0.94 & 1.02 \\
\hline \multirow[t]{2}{*}{ AZAMGARH } & SGR & 1.86 & 0.69 & 1.16 \\
\hline & CGR & 1.82 & 0.70 & 1.12 \\
\hline \multirow[t]{2}{*}{ GHAZIPUR } & SGR & 2.12 & 0.88 & 1.30 \\
\hline & CGR & 2.10 & 0.88 & 1.21 \\
\hline \multirow[t]{2}{*}{ AYODHYA } & SGR & 0.70 & 1.19 & -0.52 \\
\hline & CGR & 0.66 & 1.18 & -0.52 \\
\hline \multirow[t]{2}{*}{ SULTANPUR } & SGR & -2.54 & -3.03 & 0.47 \\
\hline & CGR & -2.86 & -3.28 & 0.40 \\
\hline \multirow[t]{2}{*}{ GORAKHPUR } & SGR & 1.63 & 0.43 & 1.21 \\
\hline & CGR & 1.50 & 0.43 & 1.05 \\
\hline \multirow[t]{2}{*}{ MAU } & SGR & 1.56 & 1.41 & -0.47 \\
\hline & CGR & 1.47 & 1.69 & -0.22 \\
\hline \multirow[t]{2}{*}{ BALIA } & SGR & 1.86 & 0.42 & 1.45 \\
\hline & CGR & 1.82 & 0.39 & 1.38 \\
\hline \multirow[t]{2}{*}{ PRAYAGRAJ } & SGR & 0.67 & 0.63 & 0.15 \\
\hline & CGR & 0.60 & 0.62 & -0.05 \\
\hline \multirow[t]{2}{*}{ BASTI } & SGR & 1.32 & 0.26 & 1.04 \\
\hline & CGR & 1.23 & 0.26 & 0.96 \\
\hline \multirow[t]{2}{*}{ GONDA } & SGR & 0.53 & 0.10 & 0.46 \\
\hline & CGR & 0.52 & 0.08 & 0.44 \\
\hline
\end{tabular}




\begin{tabular}{|c|c|c|c|c|}
\hline \multirow[t]{2}{*}{ MIRZAPUR } & SGR & 0.46 & -0.43 & 1.02 \\
\hline & CGR & 0.46 & -0.47 & 0.94 \\
\hline \multirow[t]{2}{*}{ BAHARAICH } & SGR & 1.31 & 1.92 & 1.50 \\
\hline & CGR & 1.29 & 2.01 & 1.51 \\
\hline \multirow[t]{2}{*}{ PRATAPGARH } & SGR & 1.06 & 0.34 & 0.85 \\
\hline & CGR & 0.91 & 0.32 & 0.59 \\
\hline \multirow{2}{*}{$\begin{array}{c}\text { SIDDHARTH } \\
\text { NAGAR }\end{array}$} & SGR & 3.66 & 1.44 & 2.06 \\
\hline & CGR & 3.67 & 1.52 & 1.95 \\
\hline \multirow[t]{2}{*}{ MAHARGANJ } & SGR & 2.13 & 0.73 & 1.36 \\
\hline & CGR & 2.16 & 0.74 & 1.37 \\
\hline \multirow[t]{2}{*}{ SONBHADRA } & SGR & 3.72 & -0.15 & 3.76 \\
\hline & CGR & 3.66 & -0.15 & 3.81 \\
\hline \multirow[t]{2}{*}{ KASAUMBI } & SGR & 1.79 & 1.27 & 0.58 \\
\hline & CGR & 1.69 & 1.28 & 0.40 \\
\hline \multirow[t]{2}{*}{ BHADOHI } & SGR & 0.64 & 0.35 & 0.31 \\
\hline & CGR & 0.52 & 0.35 & 0.17 \\
\hline \multirow[t]{2}{*}{ BALRAMPUR } & SGR & 1.33 & -0.59 & 1.86 \\
\hline & CGR & 1.35 & -0.56 & 3.81 \\
\hline \multirow[t]{2}{*}{ DEORIA } & SGR & 1.60 & 0.99 & 0.71 \\
\hline & CGR & 1.52 & 1 & 0.60 \\
\hline \multirow[t]{2}{*}{ KUSHINAGAR } & SGR & 0.93 & 0.58 & 0.38 \\
\hline & CGR & 0.82 & 0.59 & 0.23 \\
\hline \multirow{2}{*}{$\begin{array}{c}\text { SANT KABIR } \\
\text { NAGAR }\end{array}$} & SGR & 1.93 & 0.56 & 1.40 \\
\hline & CGR & 1.98 & 0.57 & 1.40 \\
\hline \multirow[t]{2}{*}{ SHRAWASTI } & SGR & 0.57 & -2.33 & 2.32 \\
\hline & CGR & 0.59 & -1.86 & 2.50 \\
\hline \multirow{2}{*}{$\begin{array}{c}\text { AMBEDKAR } \\
\text { NAGAR }\end{array}$} & SGR & 1.23 & 0.38 & 0.88 \\
\hline & CGR & 1.19 & 0.38 & 0.82 \\
\hline \multirow[t]{2}{*}{ BARABANKI } & SGR & 3.03 & 1.58 & 1.54 \\
\hline & CGR & 3.18 & 1.65 & 1.50 \\
\hline
\end{tabular}


Fig.1 Production and area of wheat based on 3 years moving average for the top 5 districts

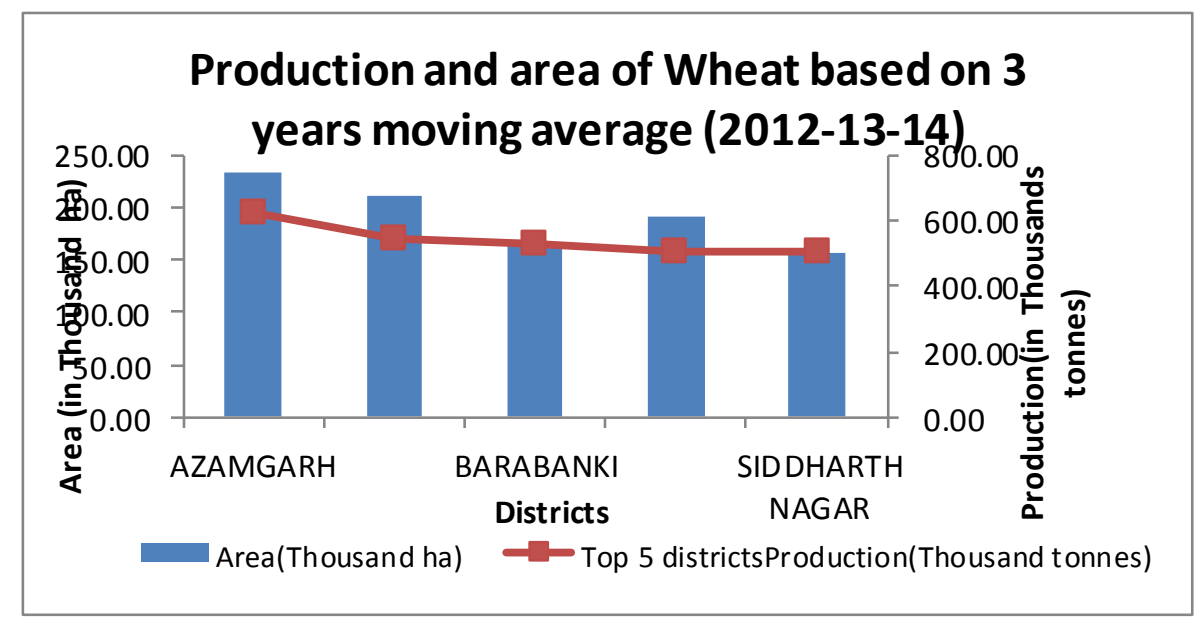

Fig.2 Productivity of top 5 districts in productivity according to production based on 3 years moving average

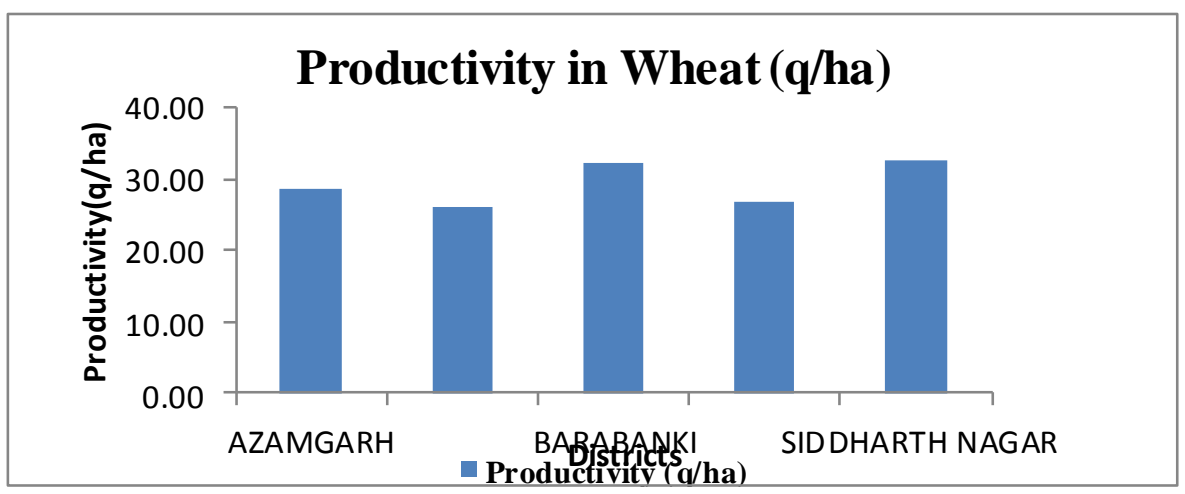

Fig.3 Productivity of top districts in wheat according to production based on 3 years moving average

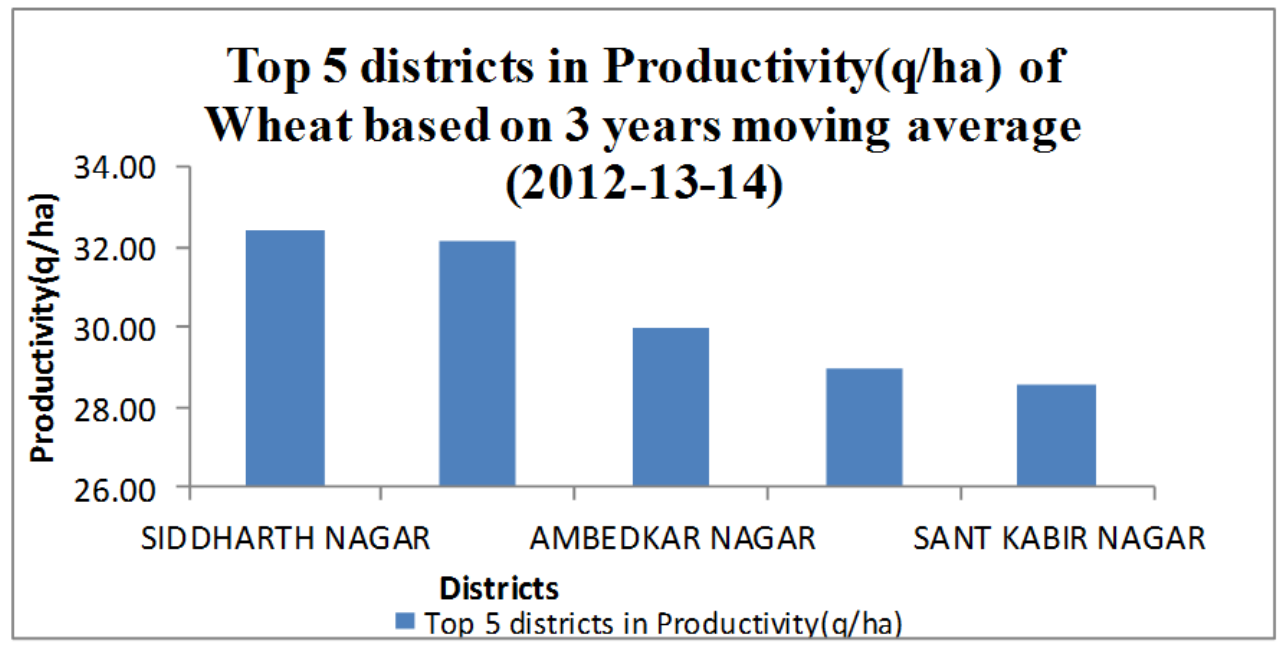


Similarly, Elumalai Kannan also reported that during the period 2000-01 to 2007-08 the Compound growth rate of wheat for area 1.25 percent, production 1.38 percent with its productivity 0.13 percent in India.

Siddharth Nagar has been among the top districts in production (i.e. $506342 \mathrm{mt}$ ) based on 3 years moving average.

Highest growth rate in production (i.e.3.67 percent) has been observed in Siddharth Nagar.

SiddharthNagar has been among the top districts in growth rate of area (i.e. 1.52 percent).

Siddharth Nagar has been among the top districts in growth rate of productivity (i.e. 1.95 percent).

Above results show that Siddharth Nagar has been leading from other districts of Eastern U.P. The reason behind its lead is Siddharth Nagar belongs to Tarai belt which has clayey loam and moderate water holding capacity making it suitable for wheat production.

\section{References}

Singh, M. and Supriya, K. (2017). Growth Rate and Trend Analysis of Wheat Crop in Uttar Pradesh. Int. J. Curr. Microbial. App. Sci. 6(7): 2295- 2301.

Pant, N. (2004). Trends in Grounwater Irrigation in Eastern and Western U.P. Economic and Political Weekly, 39(31): 3463-3468.

Singh, A.J; Bhuller B.S. and Singh, N. (1994). Growth Trends in Punjab Agriculture, Ind. J. of Agri. Econ, 35(4): 29.

Tewari, H; Singh, H.P. and Tripathi, U. (2017). Growth and Instability in Wheat Production: A Region Wise Analysis of Uttar Pradesh. International Journal Current Microbial Applied Sciences 6(9): 2537-2544.

Singh, A. and Srivastava, R. S. L. (2003). Growth and instability in sugarcane production in Uttar Pradesh: a regional study. Indian Journal of Agricultural Economics, 58(2): 279-282.

\section{How to cite this article:}

Anvesha Singh, Sri Sunil Kumar, Gopal Krishna Tiwari, Laxmi Devi and Babulal. 2020. A Statistical Study of Trends of Wheat Production in Districts of Eastern Uttar Pradesh. Int.J.Curr.Microbiol.App.Sci. 9(04): 158-166. doi: https://doi.org/10.20546/ijcmas.2020.904.020 